\title{
Potential for Upgrading in Financialised Agri-food Chains: The Case of Ghanaian Cocoa
}

\author{
Sophie van Huellen ${ }^{1} \cdot$ Fuad Mohammed Abubakar ${ }^{2}$
}

Accepted: 4 December 2020 / Published online: 4 February 2021

(c) European Association of Development Research and Training Institutes (EADI) 2021

\begin{abstract}
We revisit functional upgrading opportunities for developing and emerging market companies in the context of highly financialised food systems. We argue that the assessment of upgrading potential within the global value chain literature lacks consideration of constraints posed by financialisation, not only of the sector within which upgrading takes place but also by the global financial architecture more broadly. For the Ghanaian cocoa-chocolate sector, we show that financialisation acts as limiting factor to upgrading, with contradicting tendencies. First, financialisation of lead firms, eager to outsource non-core activities, has promoted cocoa processing in Ghana, but the resulting consolidation of power hinders further functional upgrading. Second, Ghana's dependency on cocoa for foreign exchange earnings necessitates upgrading into higher value-added segments, while also undermining feasible upgrading strategies that build on domestic or regional markets first. These contradicting tendencies constitute a middle value-added trap, which is difficult but not impossible to overcome.
\end{abstract}

Keywords Agri-food C Cocoa · Financialisation · Ghana - Global value chains · Upgrading

\section{Résumé}

Nous revisitons les opportunités de modernisation fonctionnelle des entreprises sur les marchés en développement et émergents, dans un contexte où les systèmes alimentaires sont hautement financiarisés. Nous soutenons que, dans la littérature sur les chaînes de valeur mondiale, l'évaluation du potentiel de modernisation ne tient pas compte des contraintes posées par la financiarisation, non seulement du secteur dans lequel la modernisation a lieu, mais aussi plus largement par l'architecture financière mondiale. Pour la filière cacao-chocolat ghanéenne, nous montrons que

Sophie van Huellen

sv8@soas.ac.uk

1 Department of Economics, SOAS University of London, London, UK

2 Cocoa Marketing Company GH Ltd, Accra, Ghana 
la financiarisation agit comme un facteur limitant pour la modernisation, avec des tendances contradictoires. Premièrement, la financiarisation des entreprises leader dans leur domaine, désireuses d'externaliser les activités non essentielles, a favorisé l'industrie du cacao au Ghana, mais la consolidation du pouvoir qui en résulte entrave la poursuite de la modernisation fonctionnelle. Deuxièmement, la dépendance du Ghana vis-à-vis du cacao pour ses recettes en devises nécessite une modernisation vers des branches à plus forte valeur ajoutée, tout en sapant également les stratégies de modernisation réalisables qui s'appuient d'abord sur les marchés nationaux ou régionaux. Ces tendances contradictoires représentent le piège de la valeur ajoutée intermédiaire, qu'il est difficile mais pas impossible de surmonter.

JEL F23 $\cdot$ F63 $\cdot$ L16 $\cdot$ L66 $\cdot$ O13

\section{Introduction}

Financialisation is increasingly recognised as a driving force in shaping global agrifood chains. In the tradition of the shareholder value doctrine (see e.g. Froud et al. 2000, Lazonick and O'Sullivan 2000), financialisation has been linked to a growing tendency of food multinationals to outsource lower value-added upstream activities and to an increasing concentration of the higher value-added downstream segments via mergers and acquisitions, a development that has reshaped how food is being sourced, processed and sold globally; see Ponte and Gibbon (2005), Palpacuer (2008), Palpacuer and Tozanli (2008). Studies in the food systems literature have further documented the extensive penetration of agri-food chains by the financial sector, and Burch and Lawrence (2009) proclaimed the arrival of a new financialised food regime in which the distinction between financial actors and food companies is increasingly blurred; see, also, Clapp (2014), Isakson (2014), Salerno (2014), Baines (2017), Clapp and Isakson (2018).

Drawing on these two strands of literature, this paper explores how financialisation has shaped upgrading potential for companies in developing and emerging market economies, taking as a case study the Ghanaian cocoa-chocolate sector.

West Africa contributes more than $70 \%$ of the world's cocoa production, yet the production of consumer chocolate- and cocoa-containing foodstuff takes place predominantly in the global North. While this overall pattern persists, processing at origin has expanded over recent decades, gradually shifting the West African cocoa sector from low to medium value addition. Resistance of the Ghanaian government to fully liberalise its cocoa sector has enabled Ghana to retain chocolate production capabilities, and a domestic consumer chocolate-producing sector has begun to emerge. However, the sector's expansion has been slow, raising the question of what are the limiting factors?

We argue that financialisation is an important limiting factor. More specifically, we argue that the general assessment of upgrading potential within the global value chain (GVC) literature (see e.g. Gereffi 1999; Humphrey and Schmitz 2002) lacks consideration of constraints posed by financialisation, not only of the sector 
within which upgrading takes place but also by the global financial architecture and national institutions within the architecture more broadly. We adopt Epstein's (2019, p. 380) definition of financialisation as the "increasing importance of financial markets, financial motives, financial institutions, and financial elites in the operation of the economy and its governing institutions, both at the national and international levels". For the Ghanaian cocoa-chocolate sector, we show that financialisation, both at the sector level and the level of globalised finance, acts as limiting factor to upgrading, with contradicting tendencies. First, although an increasing tendency to outsource cocoa processing, driven by the financialisation of lead firms, has contributed to the build-up of middle value-added processing capacity in Ghana, the simultaneous increase in concentration of power at the lead firm segments prevents functional upgrading into higher value-added segments. Second, dependency of the Ghanaian economy on cocoa bean exports for foreign exchange earnings necessitates the move into higher value-added segments, but at the same time prevents feasible upgrading strategies, which build on domestic or regional markets first. These contradicting tendencies constitute a middle-value-added trap, which is difficult but not impossible to overcome, as recent developments in the Ghanaian cocoa-chocolate sector demonstrate.

The paper is structured as follows. In "The Potential for Upgrading in Financialised Agri-food Systems", we review the literature on the financialisation of global agri-food systems, and then evaluate how the identified financialisation tendencies at the sector level and the level of globalised finance hinder and promote upgrading opportunities for companies in developing and emerging markets. "Upgrading Potential in the Ghanaian Cocoa Sector" evaluates these hypotheses on the example of the Ghanaian cocoa-chocolate sector, examining financialisation at the sector level and at the level of globalised finance and how these financialisation tendencies act as limiting factors to functional upgrading. "Conclusion" concludes with policy suggestions and an outlook for future research.

\section{The Potential for Upgrading in Financialised Agri-food Systems}

Globally dispersed production networks have been welcomed as an opportunity for developing and emerging market companies to acquire knowledge and skills to upgrade into higher value-added activities (Gereffi 1999; De Marchi et al. 2017). Industrialisation via GVC inclusion was widely seen as a more gradual and feasible alternative to the commodity-financed import substitution strategies dominant in previous decades until countries tumbled into high indebtedness during the commodity crises of the 1980s and 1990s (Maizels 1994). The GVC literature emerged (among other traditions) from the dependency theories of the 1950s and the observation of unequal gains from trade identified by the Prebisch-Singer hypothesis, a tradition that firmly rejects the Ricardian comparative advantage narrative (Bair 2005). With international trade relations transformed into globally dispersed production networks, the question arises whether and under which conditions the new era of globalised production can provide 
opportunities to avoid previous pitfalls of declining terms of trade by diversifying into higher value-added segments of global production networks.

Initial optimism about upgrading opportunities via GVC inclusion in the early 1990s was dampened by empirical evidence that presented a mixed picture. Humphrey and Schmitz $(2000,2004)$ explained the varied evidence by linking upgrading opportunities to the governance structure of GVCs. They concluded that in quasi-hierarchical chains, which are the prevailing structure in North-South stretched production networks, product and process upgrading, i.e. producing more sophisticated products more efficiently, is achievable; however, functional upgrading, i.e. acquiring new functions to increase the overall skill content of activities to move the producer into a higher value-added segment of the chain, is difficult to achieve (Humphrey and Schmitz 2004, p. 1020). This is due to two hindrances: buyer resistance and resource requirements.

The identification of these hindrances has led to a reconsideration of the role of the state in creating upgrading opportunities; e.g. see Mayer and Phillips (2017), Pipkin and Fuentes (2017), Horner and Alford (2019). Inspired by the success of the economies of Korea, Taiwan and China, Lee et al. (2017) developed the 'in-out-in' hypothesis which suggests iterative learning and absorption of technologies through inclusion, followed by exclusion and infant industry protection to fend off competitors and establish own brands. Hauge (2020) made a similar argument, drawing on the experiences of South Korea and Taiwan, and Lombardozzi (2020) demonstrated how targeted macroeconomic policies have enabled upgrading in Uzbekistan's horticulture sector. These contributions reconsider and emphasise the leading role of the state in shaping upgrading opportunities.

In addition to doubts about upgrading via inclusion, a more fundamental critique emerged that questioned the social and economic benefits of upgrading. For instance, Vicol et al. (2018) showed that upgrading in the Indonesian coffee sector reproduced and manifested local patterns of inequality, doing little for poverty alleviation. Rossi (2013) demonstrated that functional upgrading can lead to both social downgrading and upgrading for different groups of workers among Moroccan garment suppliers. Fagerberg et al. (2018) further found that countries with less well-developed capabilities lose with GVC inclusion. All three studies confirm the possibility of downgrading via inclusion; see Kaplinsky (1998) on 'immiserising growth', more generally. Bair and Werner (2011) and Bair et al. (2013) further pointed out that the GVC literature suffers from inclusionary bias. As the process of inclusion into global markets implies redrawing the boundaries of the market, it is also a process of exclusion. Although often overlooked, these considerations on downgrading and exclusion are of paramount importance to not only understanding the mixed evidence on outcomes of GVC inclusion but also the political economy of upgrading and motives of governments and other stakeholders to support and design upgrading strategies; see Behuria (2019).

\section{Financialised Agri-food Systems}

Globally dispersed production emerged out of a reorientation of corporate strategy, mainly at the high-value branding segment. Expansion in this segment is predominantly achieved through mergers and acquisitions, while lower value-added 
activities are outsourced to upstream suppliers (Gereffi 1999). This change in corporate strategy from 'retain and reinvest' to 'downsize and distribute' has been recognised as a consequence of financialisation; see Lazonick and O'Sullivan (2000) and Froud et al. (2000). The term emerged outside of the GVC literature but is increasingly recognised for its relevance to understanding the changing nature of global production networks; see Milberg and Winkler (2009), Baud and Durand (2011), Auvray and Rabinovich (2017). In the tradition of the shareholder value doctrine, dwindling profits in domestic markets are linked to an increasing tendency of corporations to turn towards financial returns as a new source of profit. Following this logic, outsourcing is motivated by an attempt to divest from low return on capital employed (ROCE) activities such as inventory management to boost share value (Gibbon 2001; Baud and Durand 2011).

Financialisation of agri-food systems, more specifically, take on the form of two interlinked and mutually reinforcing tendencies of which the shareholder value doctrine is one (Isakson 2014). First, agri-food corporations increasingly shift their attention to financial forms of capital accumulation, summarised by Baud and Durand (2011) as financialisation of objectives, investment and operations. Second, food-based assets are created and made available to financial investors. As described by Burch and Lawrence (2009, p. 277), these tendencies result in "finance institutions becoming increasingly involved in the agri-food system while agri-food companies come increasingly to behave like financial institutions". The blurring lines between financial and non-financial corporations in the agri-food sector are mapped in Fig. 1.

To explain Fig. 1 in more detail, we must identify the lead segments of agri-food chains first. Agri-food chains have been characterised as multipolar (Fold 2002; Fold and Larsen 2011), distinguishing them from manufacturing-based chains, which are commonly categorised within Gereffi's (1999) buyer-driven and producer-driven taxonomy. ${ }^{1}$ Following the tripolar division by Fold and Larsen (2011), agri-food chains are governed by three lead segments: retailers that are selling branded food products, branders with ownership over a variety of brand names and first-tier suppliers that source inputs and provide both branders and retailers with intermediate and ready-to-sell products. ${ }^{2}$ Among these different lead segments, first-tier suppliers are the most powerful, exercising control over the entire upstream supply chain (Gibbon 2001). ${ }^{3}$

As shown in Fig. 1a, the financialisation of branders can be understood along the lines of the shareholder value doctrine, with both financialisation of objectives and investments discernible, while the first-tier supplier and retail segments are financialised along all three dimensions. Actors in these lead segments have

\footnotetext{
${ }^{1}$ Fresh fruit and vegetable chains are an exception, as these chains can be characterised as buyer-driven, with retailers acting as lead firms (Dolan and Humphrey 2000).

2 The distinction between lead segments is less sharp than suggested here. The first-tier supplier segment comprises trading houses and processing companies. Some of the branders engage in food processing and retailers increasingly promote own brands.

3 Others argue that retailers are the most powerful actors due to their control over shelf space, e.g. Palpacuer and Tozanli (2008), Burch and Lawrence (2009), Isakson (2014).
} 

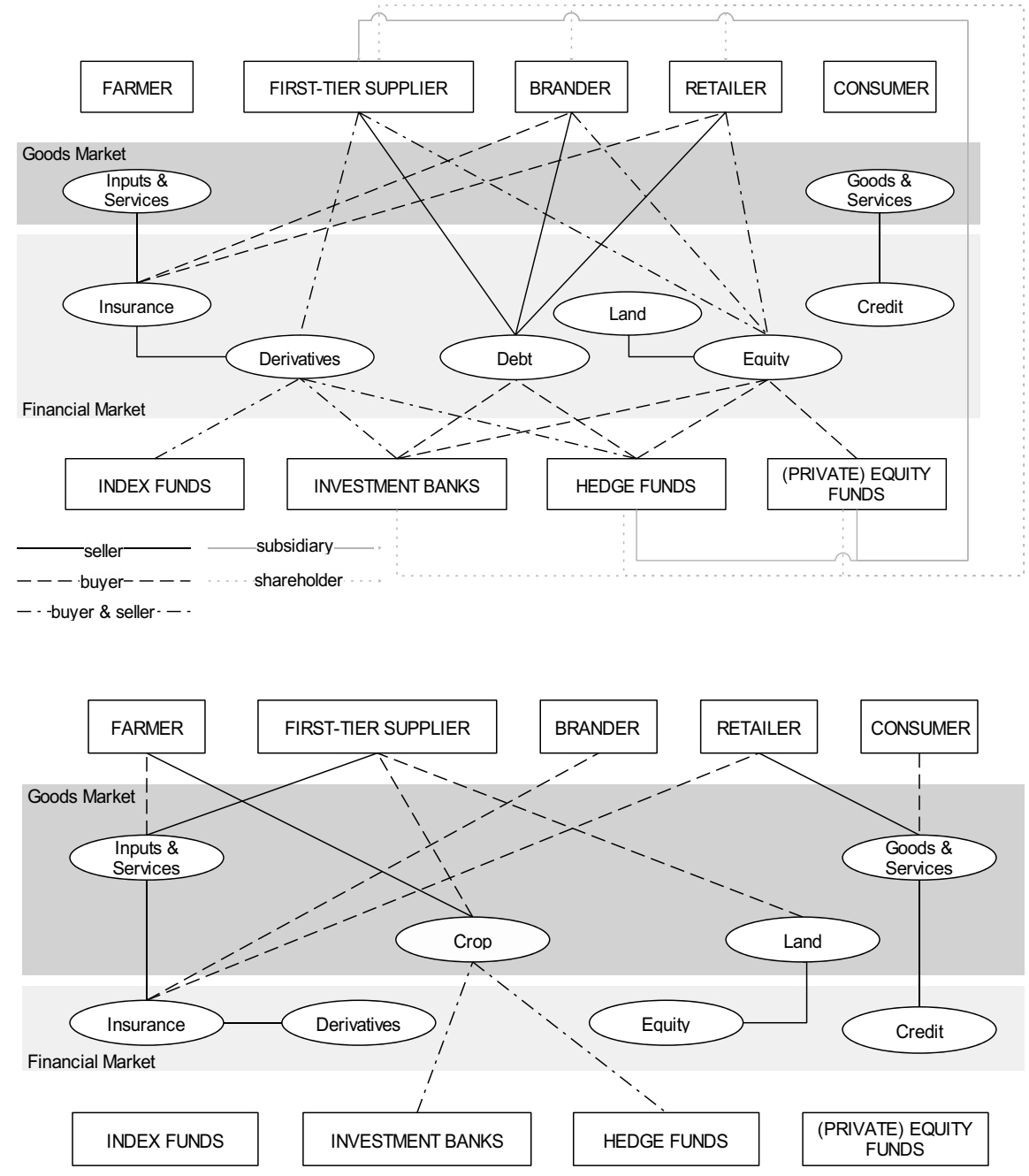

Fig. 1 Financialisation of agri-food industries. a Non-financial actors' involvements in the financial markets. b Financial actors' involvements in the goods markets. Source Authors

diversified into financial operations, now offering financial services, such as insurance and credit, to their clients and counting hedge funds and other investment funds among their subsidiaries. Further, the growing presence of institutional investors as major shareholders has reshaped all three lead segments; e.g. see Palpacuer and Tozanli (2008), and Palpacuer (2008). Palpacuer and Tozanli (2008) found a strong positive association between the presence of institutional investors and the global reach, including offshoring and outsourcing tendencies, of a company's strategies between the 1980s and early 2000s. Palpacuer (2008) further showed that food multinationals increasingly engage in share buy backs and growth through mergers and 
acquisitions, rather than investment in productive capacity. Baud and Durand (2011) reported similar tendencies in line with the shareholder value doctrine in the retail segment. Retailers have shifted increasingly to ROCE-friendly strategies such as the imposition of just-in-time delivery to minimise inventory holdings. Isakson (2014) further documented how structural adjustment programmes and liberalisation in the Global South has enabled the expansion of retail giants through merger and acquisition into non-traditional markets. The retail segment is thus becoming increasingly globalised and concentrated, shifting powers within global agri-food chains. Retailers have further diversified into financial investments and operations, freeing funds for financial activities by extending the time between delivery and payment, and offering their customers financial products, such as credit and prepaid debit cards, savings and checking accounts and insurance programmes; see Burch and Lawrence (2009), Baud and Durand (2011), Isakson (2014).

Among the three lead segments, first-tier suppliers are arguably the most financialised. Not coincidentally, the segment has the longest tradition and capabilities in financial trading and operations. The tendency to outsource low-ROCE activities at the brander segment has facilitated the transformation of the first-tier supplier segment, which has emerged from a fusion of trading houses and processing companies into large conglomerates. The segment is now highly concentrated, with the so-called ABCD traders, an acronym of the four giants Archer Daniels Midland (ADM), Bunge, Cargill and Louis Dreyfus controlling a 70\% market share of global grain trade (Murphy et al. 2012; Clapp 2015). Alongside an increasing concentration of this lead segment, first-tier suppliers have also vertically integrated and diversified via acquisition of stakeholders along the chain (Clapp 2015). Today, ABCD traders operate on all levels of the food commodity chain, including the provision of agricultural inputs, intermediate products, services and end products (Murphy et al. 2012; Salerno 2014). The drive to diversify encompasses more traditional activities, such as trading and processing of food commodities, but also new areas of capital accumulation taking place in the sphere of finance rather than production (Clapp 2015).

First-tier suppliers have always been key players in commodity derivative markets for risk management (Salerno 2014). ${ }^{4}$ However, they now increasingly offer financial services (e.g. price and quantity risk insurance products) to other members of the supply chain including commodity producers. At the same time, their market dominance provides them with an information advantage, which they use for speculative trading (Clapp 2014, 2015; Isakson 2014; Salerno 2016). Some maintain several financial subsidiaries, such as hedge funds and private equity funds, to gain from speculation and enhance control over commodity production and land. For instance, Black River Asset Management and CarVal Investors are financial subsidiaries of Cargill, the largest among the ABCD traders, and the hedge funds Alpha Fund and Calyx Agro are subsidiaries of Louis Dreyfus; see Salerno $(2014,2016)$

\footnotetext{
${ }^{4}$ First-tier suppliers have always been engaged in some degree of speculation via strategic hedging (Working 1960), but the addition of hedge funds and other investment funds to their business portfolio is a new development.
} 
on Cargill and Murphy et al. (2012), Isakson (2014), more generally. Interestingly, Cargill and Louis Dreyfus, the most active in the hedge fund business are the only two of the four giants that are not publicly listed, allowing them a higher level of secrecy about their operations than ADM and Bunge (Murphy et al. 2012).

The expansion of first-tier suppliers into financial operations and services was facilitated by sweeping deregulation of commodity derivative markets in the early 2000s, evolving alongside an increasing penetration of the commodity sector by financial investors, especially institutional investors via index funds, as shown in Fig. 1b; see Mayer (2012), Clapp and Helleiner (2012). Deregulation enabled investment banks and funds to create complex risk management tools and offer these to commodity producers, processors and consumers as insurance products. At the same time, derivatives based on weather, water, food, fuel, fertiliser and farmland have become increasingly attractive for financial speculators in search of higher yield in a low-interest rate environment (Erb and Harvey 2006; Gorton and Rouwenhorst 2006). The entrance of new types of speculators into commodity markets fuelled price volatility and speculative bubbles, escalating into two world food crises in 2007-08 and 2010-11; e.g. see Ghosh (2010), Nissanke (2012). Additionally, stocks (equity) and bonds (debt) of commodity-based companies were packaged into indices managed by hedge funds, most prominently Black Rock, becoming a prominent part of wealth managers' portfolios. Large investment banks are investing heavily in funds specialising in food commodity equity or derivatives; see Isakson (2014). Investment banks have even attempted to invest in physical commodities (e.g. J. P. Morgan entertained a physical commodities unit until 2014), while hedge funds associated with first-tier suppliers have exploited their capabilities in both derivative trading and commodity storage, which puts them in a unique position among speculative investors.

\section{Financialisation and the Potential for Upgrading}

Financialisation of objectives among food multinationals has contributed to an increasing tendency of outsourcing and offshoring of lower value-added production processes, resulting in opportunities for developing and emerging markets to integrate into GVCs. At the same time, financialisation of investments has resulted in formidable market power at the lead segments. All three agri-food lead segments are characterised by oligopolistic competition, as corporations widen their global reach. First-tier suppliers have further consolidated their market power through vertical integration, exercising firm control over their supply chains (De Medeiros 2017). The modularity of production processes that permits outsourcing has also enabled lead firms to choose locations flexibly, undermining bargaining power of suppliers; see Palpacuer (2008). Given their market power, lead firms have been able to impose quality and other product definitions via standards and certificates, the costs of which are predominantly carried by the supplier; see Ponte and Gibbon (2005).

Financialisation of operations has further provided retailers and first-tier suppliers with a competitive edge, which is difficult to match by companies with headquarters outside financial centres (De Medeiros 2017). In a financialised food system, 
information gathering and control are important reasons for lead firms to maintain quasi-hierarchical chains, characterised by a high degree of control. The scale and diversification of their operations has enabled lead firms to thrive in times of volatility, while acting as barriers to entry for smaller competitors (Isakson 2014; Salerno 2014). The diversification of operations through vertical integration and the move into financialisation of operations requires newcomers to have access to deep and cheap capital markets to compete, a difficult requirement for most developing and emerging market companies.

Financialisation has therefore contributed to barriers to entry and to cementing of power asymmetries between multinational lead firms and their suppliers, undermining the latter's prospects for functional upgrading. However, the upgrading constraints considered thus far fall predominantly under the 'buyer resistance category', while the second category of 'resource constraints' has not been fully explored yet. Denomination of world trade in USD requires emerging and developing market companies seeking functional upgrading opportunities to have access to deep foreign capital markets, exposing companies to foreign exchange risk. Kaltenbrunner and Painceira $(2014,2017)$ spoke of new external vulnerabilities of such companies, a structural disadvantage emerging from the currency hierarchy of the international monetary system. Reflecting on feasible upgrading strategies in highly financialised and concentrated industries, such as the 'in-out-in' hypothesis by Lee et al. (2017), reveals how the international monetary system constrains the policy space for developing and emerging countries. Implementation of upgrading strategies that rely on infant industry protection requires foregoing foreign reserve earnings in the short or medium run. Developing and emerging country economies critically rely on foreign exchange to curtail exchange rate volatility and ensure macroeconomic stability, manifested in the phenomenon of reserve accumulation. While functional upgrading is highly desirable, especially in countries which rely heavily on volatile primary commodity exports, forgoing these foreign exchange earnings in the short or medium run is not a feasible strategy.

Powell (2013), Bonizzi (2013) and Bonizzi et al. (2019) described this dilemma as one of subordinate financialisation, whereby developing and emerging market economies enter global trade and finance from a position of subordination. The subordination arises over the nature of the global monetary system and the resulting currency hierarchy, led by the USD. Emerging and developing market economies operate predominantly at the lower value-added segments. This position is cemented by the need for foreign exchange to ensure macroeconomic stability and fend off speculative attacks on currencies. The problem of the middle-value-added trap, hence, cannot be separated from the discussion around precautionary reserves holdings, adding the dimension of global finance to the more prominent angle of global production, when discussing upgrading constraints.

Financialisation, therefore, acts as limiting factor for upgrading through the (1) higher concentration of lead segments, resulting in higher barriers to entry for newcomers; and (2) heavy reliance of domestic governments on foreign exchange earnings from lower value-added product exports, including primary commodity exports. We will analyse the embodiment of these two financialisation constraints to upgrading, taking the Ghanaian cocoa-chocolate industry as an example. 


\section{Upgrading Potential in the Ghanaian Cocoa Sector}

West Africa delivers almost three-fourths of the world's annual cocoa supply. Côte d'Ivoire is the largest producer in terms of annual volume, followed by neighbouring Ghana. Cocoa prices, as with most primary commodities, are referenced against futures prices at international commodity exchanges and are highly volatile. Prices are characterised by short seasonal cycles, driven largely by demand and supply over harvesting seasons, and long growing cycles, stemming from the time trees need to mature to bear fruit, and in recent times large speculators and index funds (Gilbert 2016). The cocoa tree bears fruit throughout the year, however, with varying pod sizes. For Ghana, the cocoa crop year is divided into the main crop season, running from October to May, and the light crop season, running from June to September. Since cocoa trees only grow in a narrow climate zone around the equatorial belt, small disruptions can cause substantial shocks, further adding to price volatility.

The cocoa-chocolate sector is of primary importance for Ghana, politically and economically. An estimated one-third of Ghana's working population, directly and indirectly, depends on cocoa income. Cocoa constitutes $20 \%$ of Ghana's export earnings - the most important export after gold and, more recently, oil. While cocoa beans compete with gold and oil, cocoa products, such as liquor, butter and powder, comprise the most important untraditional exports. Overall, the cocoa sector remains the most important sector for Ghana in terms of employment, foreign reserve provision and revenue generation for the government.

Cocoa beans reach the consumer either in form of chocolate or other cocoa-containing foodstuff. Intermediate cocoa products and their bean content are depicted in Fig. 2. Cocoa butter is an essential ingredient in chocolate, whereas powder is mainly used for confectionary products. Cocoa liquor and butter are priced as a ratio to the bean price. Cocoa cake, powder and chocolate are sold on an outright basis. Among the two cocoa liquor derivatives, cocoa cake and butter, cocoa butter is the dominant value factor.

Cocoa processing and chocolate production predominantly occur in the global North. According to International Cocoa Organisation (ICCO) data, about $46 \%$ of world's grinding takes place in Europe and the United States. However, West Africa has increased its share by more than $4 \%$ points over the last decade, which has been largely due to an increase in processing capacity in Ghana and Côte d'Ivoire. Ghana has more than tripled its grinding volume since the beginning of the century, and Ghana and Côte d'Ivoire together are now contributing 19\% of world's grinding. However, the volume of consumer chocolate production in West Africa remains low.

\section{Financialisation of the Global Cocoa-Chocolate Chain}

As with most agri-food chains, the cocoa-chocolate chain is governed by a tripolar lead segment, as described in "Financialised Agri-Food Systems"; see Fold (2001, 2002 , 2007). Each lead segment is highly concentrated, manifested in both horizontal and vertical integration over the last decades. Chocolate is a luxury good, and consumer markets are limited. With sluggish growth in core markets over the last 


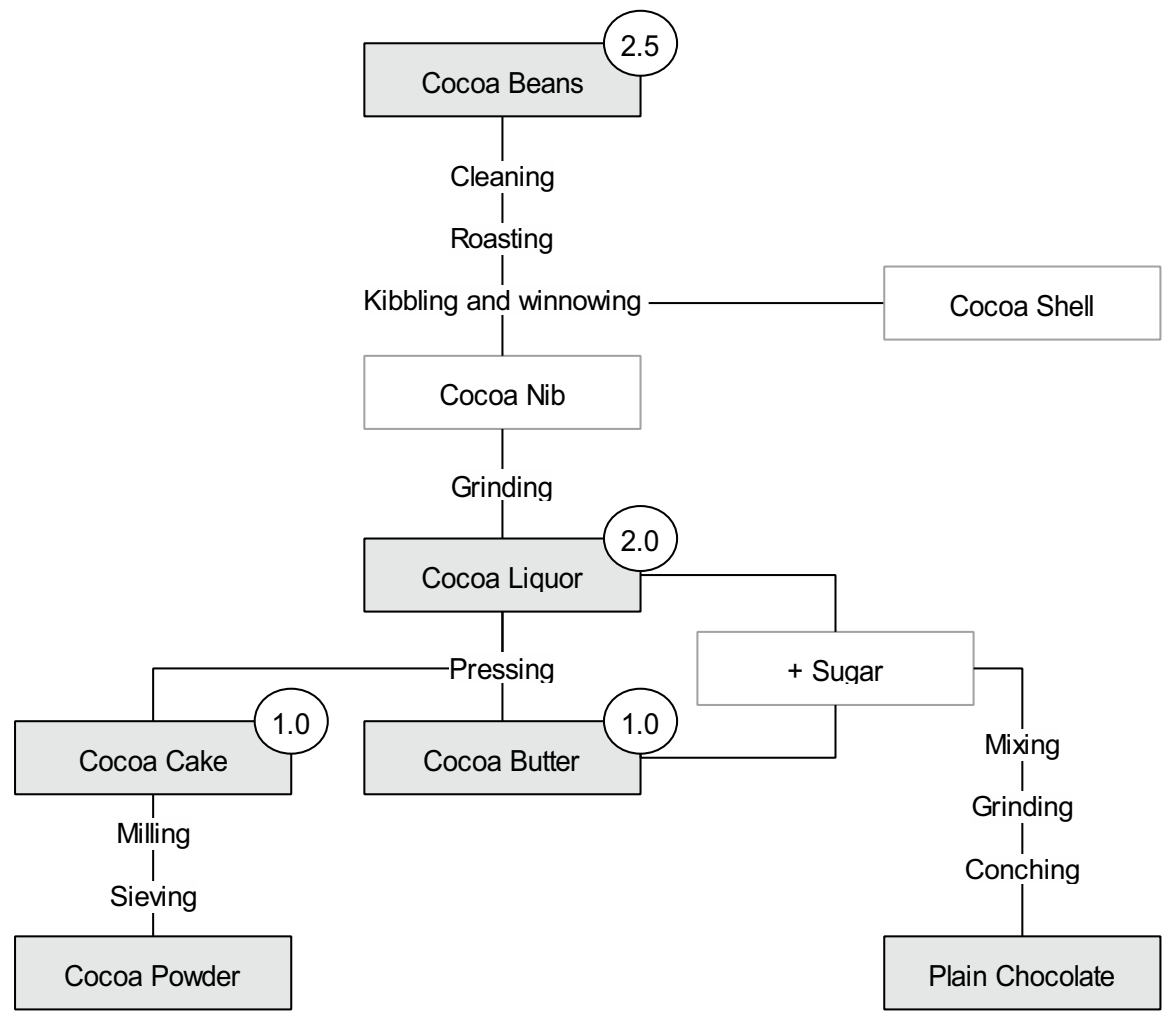

Fig. 2 Cocoa bean content, in tonnage, of intermediate products. The circled numbers denote the physical relationship in terms of tonnage. Source Graphic provided in interview with a cocoa trader in September 2013

decades, companies' growth primarily has taken place through mergers and acquisition; Fold (2001) counted more than 200 between 1970 and 1990. After years of horizontal and vertical integration, the branding segment of the confectionary sector is currently dominated by five companies: Mars, Mondelēz/Kraft Foods, Hershey, Nestlé and Ferrero. For the chocolate sector, specifically, a significant market share is also held by Lindt \& Sprüngli and, more recently, Meiji. Kraft Foods increased its share considerably in 2010, with the acquisition of Cadbury. The first-tier segment is even more concentrated. Until 2010, five companies were producing more than half of the world's semi-finished cocoa products: Cargill, ADM, Barry Callebaut, Petra Foods and Blommer. In 2012, Petra Foods, with headquarters in Singapore, sold its grinding segment to Barry Callebaut to focus on its branded consumer business. Cargill completed its acquisition of parts of ADM's cocoa operations in 2015. This left half of the world's grinding business in the hand of only two companies, Cargill and Barry Callebaut. Olam, which previously focused on cocoa sourcing and trading, entered the grinding segment through the acquisition of ADM's cocoa processing segment in 2015, and in 2018, Fuji Oil entered the cocoa processing sector 
by acquiring Blommer, a previously privately owned company based in the United States.

With reference to "Financialised Agri-Food Systems", Table 1 summarises financialisation indicators for the main branders and first-tier suppliers in the global cocoa-chocolate industry. ${ }^{5}$ Most lead firms are publicly listed companies, except for Mars, Ferrero, Cargill and Cémoi. Not coincidentally, listed companies are based in financial centres. For US companies, institutional investors are the most dominant shareholders, holding just under $80 \%$ of total shares. The weight of institutional investors is much lower for companies based elsewhere, showing national differences. For all listed companies, shareholder pay-outs in the form of dividends have steadily increased over the last three decades, indicative of financialisation of objectives. Interestingly, pay-outs by US and Swiss companies, which are dominated by institutional investors, are substantially larger than for other companies.

Financialisation of investment is evident also for both listed and non-listed companies. Goodwill, as a percentage of total assets, provides an indication of the extent to which companies engage in mergers and acquisitions. ${ }^{6}$ Most companies have acquired multiple subsidiaries, up to 200 for Mondelēz and Nestlé, which are managed via holding companies registered in financial centres and tax havens, e.g. Hershey UK Holding Limited, based in the City of London, and Ferrero International SA, based in Luxembourg. However, the types of subsidiaries among branders and first-tier suppliers differs substantially, which reflects the ways in which these two lead segments have emerged over time. Branders have mainly accumulated other brand names, furthering horizontal integration of this lead segment while subsidiaries of first-tier suppliers include companies for marketing, transport, storage, sourcing and trading, as well as agricultural service provision.

The information advantage of companies that integrate vertically enables firsttier suppliers not only to manage their risk more effectively, but also to benefit from speculative positions in the derivative markets and diversify into financial service provision. Cargill, Olam and Barry Callebaut offer commodity risk management services and market intelligence to their clients as part of their core business and use financial instruments for risk management and leverage. For instance, Olam uses repos (repurchase agreements), whereby they sell their cocoa contracts to a bank at the time of signing the contract, with an agreement to buy it back at the time of taking physical delivery of the beans. Cargill and Olam diversified into financialisation of operations via subsidiaries. Cargill's subsidiaries, which offer financial services as their primary activity, are Cargill Financial Services Corporation, for example, which provides security brokerage services; Banco Cargill, a Brazilian commercial bank; Cargill Global Funding PLC, which provides risk management solutions; and Black River Asset Management, a commodity hedge fund. The latter was sold by

\footnotetext{
5 The classification is imperfect, as some first-tier suppliers are producing their own brands as well as supplying larger brand names, e.g. Cemoi and previously, Blommer.

6 When a company is acquired, the difference between market value and book value is accounted for as goodwill on the acquiring company's asset side. These 'imaginary' assets provide an indication of the extent to which acquisitions are part of a company's growth strategy and the size by which its balance sheet is inflated (Haslam et al. 2013, Ch. 1 and 2).
} 


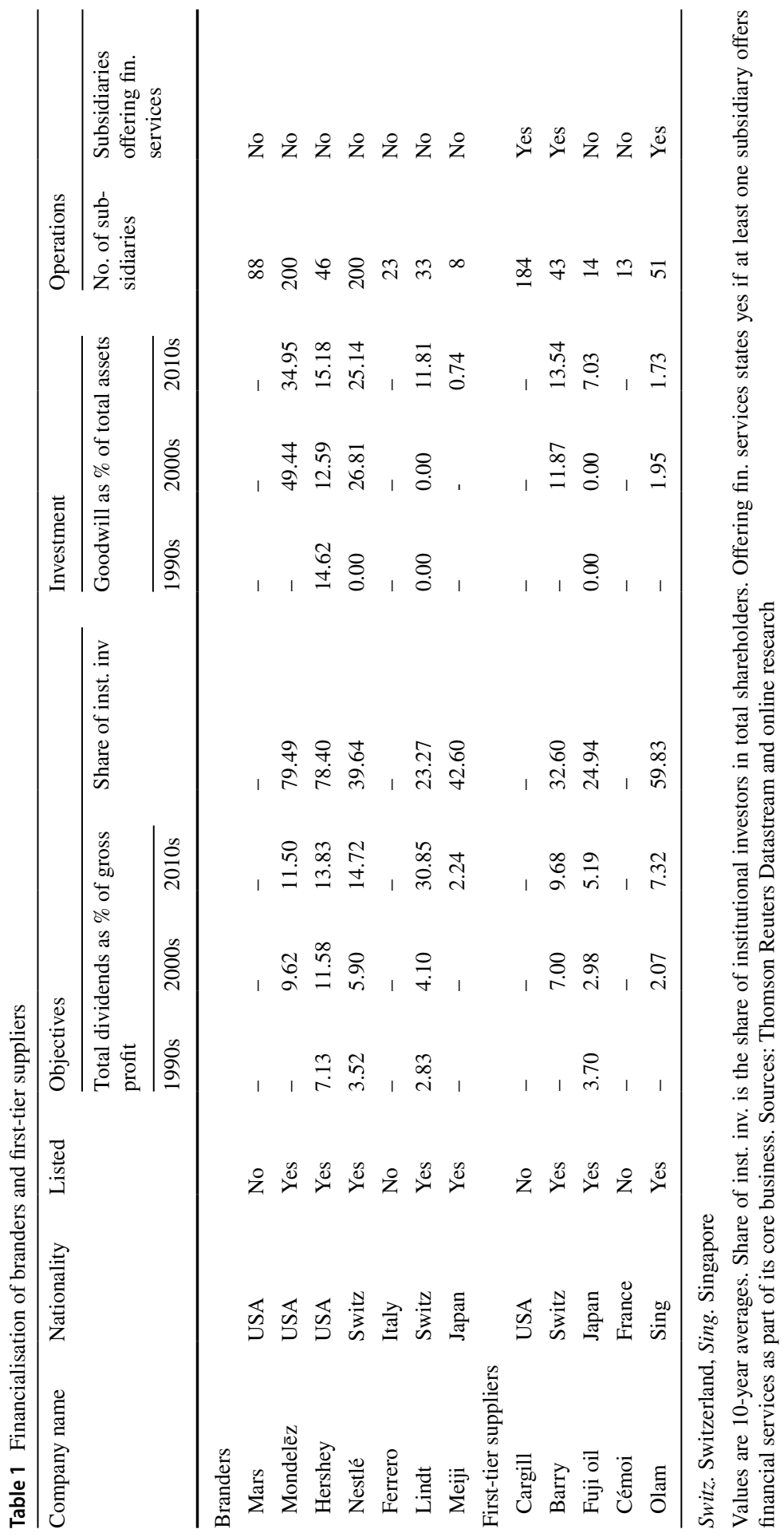



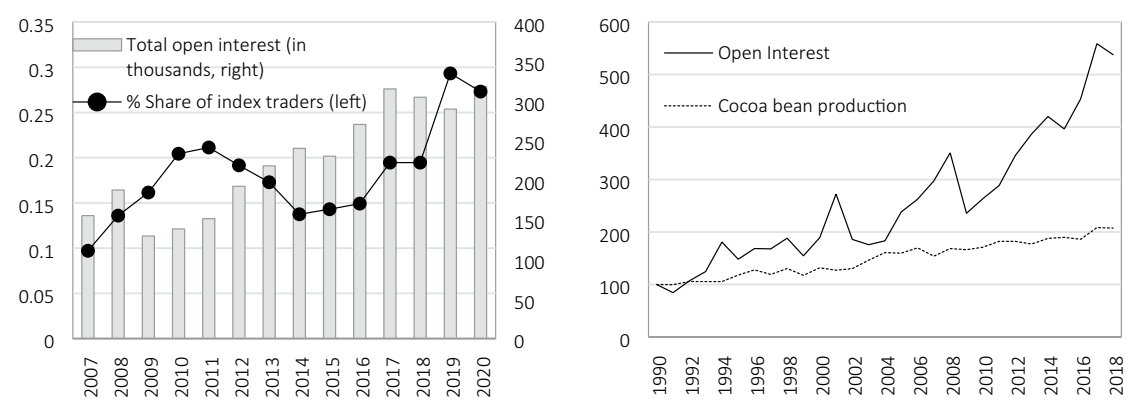

Fig. 3 Cocoa derivative investments ICE futures US and total production. Beginning of year values. Open interest and cocoa bean production on the right as index $(1990=100)$. Source Thomson Reuters Datastream; CFTC index trader supplement; FAOStats

Cargill in 2016, due to a change in regulations that prohibited insider trading for commodity markets, formerly legal. Olam's subsidiaries include Panasia International Ltd, which offers real estate investment and advisory services.

However, the information advantage of lead firms is increasingly undermined by the entrance of new actors in commodity derivative markets. Institutional investors, and specifically, index investors who invest in commodity derivatives for portfolio diversification and hedge against inflation, have been accused of undermining price discovery in commodity markets, leading to prices moving independently from market fundamentals. Figure 3 shows the increase in investment in financial cocoa derivatives (futures and options). Open interest has grown considerably steeper than cocoa bean production since 2004 , and the share of open interest attributed to index traders of total open interest has increased steadily. The development has challenged both first-tier suppliers' information advantage as well as macroeconomic management for cocoa exporting economies, as prices have become increasingly volatile and unrelated to market fundamentals.

\section{Globalised Finance and the Ghanaian Cocoa Sector}

The organisation of the Ghanaian cocoa chain has its origin in the country's colonial past (Talbot 2002). The Ghana Cocoa Board (Cocobod, hereafter) is an organisational descendant of the West African Producer Control Board, which was established in 1940, to extract revenues for British war efforts in Europe (Acquaah 1999, pp. 108-11). The extractive set-up of Cocobod was maintained after independence, with the purpose of funding an industrial base, by Ghana's first president Kwame Nkrumah (Mikell 1989, pp. 162-63). When industrialisation efforts were undermined by recurring price slumps of global commodity prices, Ghana and the cocoa sector moved into financial difficulties, and eventually, became dependent on the assistance of the International Monetary Fund (IMF). Anticipating the IMF's austerity programme in the 1980s, the Ghanaian government proactively drew up an extensive plan for financial reform, including a restructuring of the cocoa sector. 


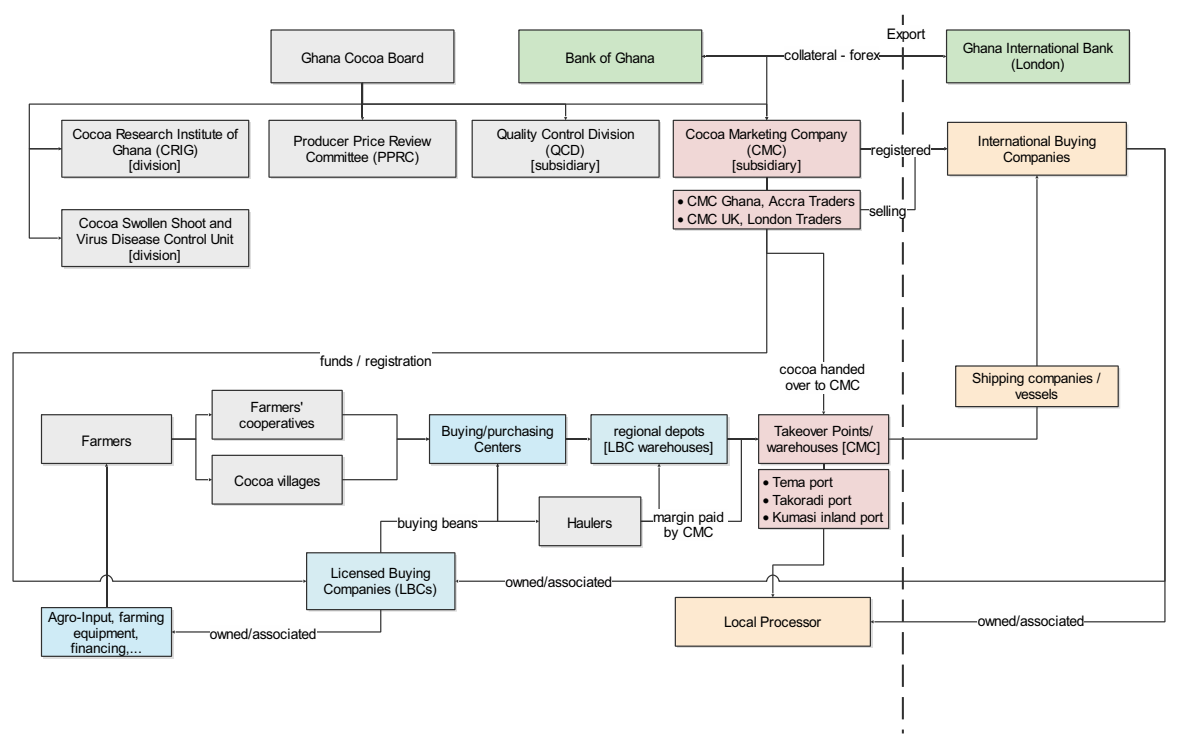

Fig. 4 The organisation of Ghana's Cocoa-Chocolate chain. Based on various interviews with cocoa stakeholders in 2013 and 2020, and the authors' knowledge of the industry. Source Authors

The restructuring envisioned a partial liberalisation, maintaining Cocobod as parastatal organisation, thereby, making Ghana the only country without a fully liberalised cocoa marketing system.

Figure 4 maps the Ghanaian cocoa chain with government, parastatal and private sector stakeholders. The Ghanaian chain can be divided into internal marketing (blue) and external marketing (yellow). The dividing line is drawn by the operations of the Cocoa Marketing Company (CMC), a subsidiary of Cocobod (red). Local buyers, so-called Licenced Buying Companies (LBCs), must deliver all cocoa beans to CMC for a fixed margin, and CMC acts as the sole seller of Ghanaian cocoa. Partial liberalisation of the cocoa sector curtails some of the benefits of vertical integration for first-tier suppliers, and for this reason, LBCs are mainly domestically owned, with few but financially competitive international ones. This is in stark contrast to neighbouring Côte d'Ivoire. Only Barry Callebaut, Armajaro ${ }^{7}$ (now AgroEcom), Olam, and more recently, Cargill and Touton have integrated vertically into sourcing cocoa in Ghana. All five companies are major players in the cocoa derivative markets.

CMC's marketing operations involve a delicate forward-selling system, enabling Cocobod to raise offshore financing to extend cheap loans to LBCs while enabling the Bank of Ghana (green), Ghana's central bank, to buy US dollars cheaply. After

\footnotetext{
7 Armajaro is a major soft commodity hedge fund and, until recently, has been a major trading company. It announced the sale of its cocoa sourcing unit in 2013, after a botched attempt to corner the market in 2010 .
} 


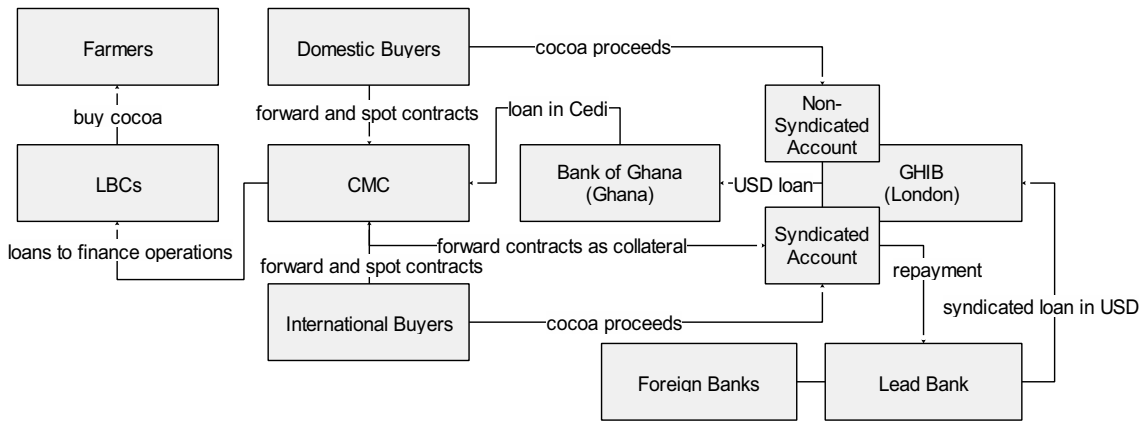

Fig. 5 Cocobod external funding through syndicate loans. The division of the international buyer-syndicated account and domestic buyer-non-syndicated accounts is for demonstration purposes only, as not all contracts with foreign buyers go into the syndicated account, and some contracts with the local processors go into the syndicated account. Source Authors. Based on various interviews with cocoa stakeholders in 2013 and 2020, and the authors' knowledge of the industry

selling up to $70 \%$ of the projected crop forward in USD, Cocobod extends cocoa funds in Cedi to LBCs below market rate. The funds are allocated to the different purchasing centres, to then provide cash advances to purchasing clerks for cocoa sourcing. After delivery, cash advances are renewed, commission is paid and loans are turned over. The forward contracts between $\mathrm{CMC} / \mathrm{Cocobod}$ and international buyers are used as security collateral by Cocobod, which enters into an annual syndicate loan agreement with multiple (international and local) commercial banks. This provides an opportunity for the Bank of Ghana to raise foreign exchange cheaply abroad via the Ghana International Bank (GHIB), based in the City of London and majority owned by the Bank of Ghana. For instance, in the 2019/20 crop year, a USD1.3 billion loan was issued by a syndicate of 21 banks at an interest rate 6 basis points over the LIBOR rate.

The process is shown in Fig. 5. CMC operates two main accounts with GHIB, one syndicated and one non-syndicated. Forward contracts with international buyers (large multinational companies) are used as collateral via the syndicated account. Contracts with some domestic buyers are often not usable as collateral, as these are deemed to be higher default risks by international lenders. Proceeds of these contracts go into the non-syndicated GHIB account. The loan is usually signed in September before the main crop season opens, putting pressure on CMC to sell enough cocoa forward in the months prior to September. When the loan is issued, the USD amount is transferred to the Bank of Ghana, which issues Cedi to Cocobod for its internal marketing operations. Once a collateralised beans contract is shipped to the buyer's instructed destination, the proceeds go into the GHIB account for loan repayment. All foreign exchange earned in the process is surrendered to the Bank of Ghana to facilitate the Bank's local currency stabilisation role and improve Ghana's balance of payments.

Through this system, Cocobod can meet the high funding requirements of cocoa purchases by gaining access to cheap foreign capital markets, and, at the same time, provide the economy with valuable US dollar reserves. Since the initiation of the 


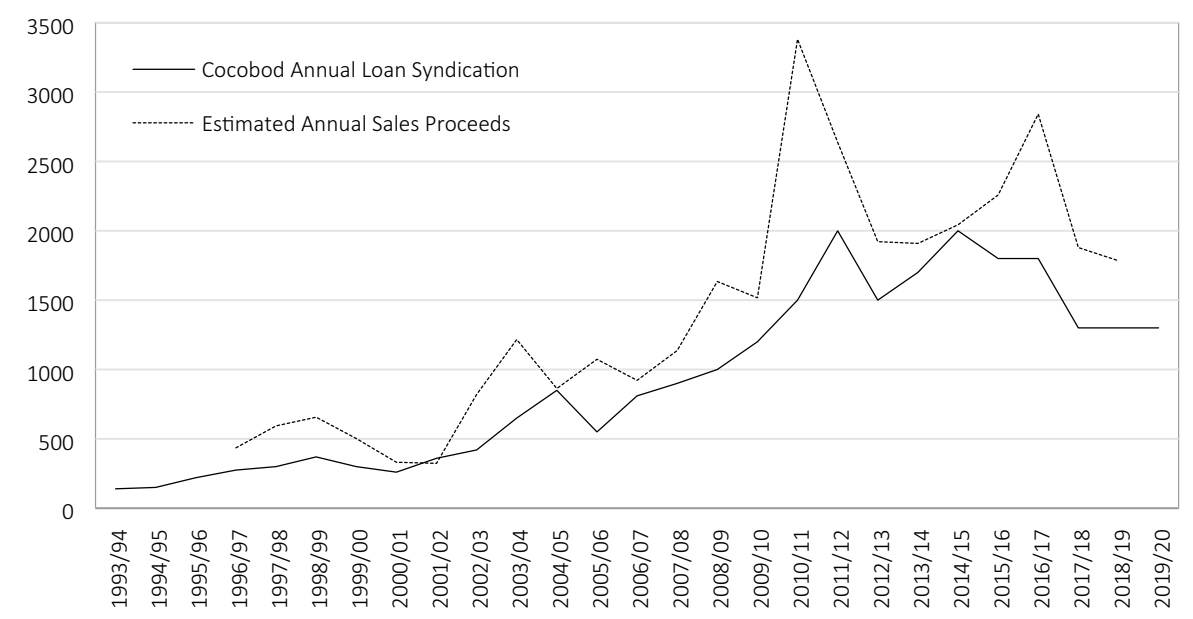

Fig. 6 Cocobod annual loan syndication and sales proceeds (in USD million). Source Data provided by CMC. Authors' calculations

syndicated loan system in the 1992/93 crop season, a total of over US $\$ 25$ billion has been sourced; see Fig. 6. The use of syndicate loans is unique in the cocoa-chocolate industry. However, a similar system has been used by other African economies to achieve affordable rates in international markets through their commodity wealth, e.g. Angolan state oil company Sonangol and Nigerian cement group Dangote.

Beyond the annual syndicated loan, Cocobod also borrows from the Bank of Ghana, albeit at more expensive terms, to finance some of its cocoa sourcing operations, especially the minor crop seasons. So-called cocoa bills with the Bank of Ghana have accumulated over the decades, and Cocobod recently accessed loans from the international market to repay these. The repayment was facilitated by two 3-year loans over US\$300 million in 2015 and 2018, providing the Bank of Ghana with additional foreign reserves. Further, Cocobod/CMC, at times, sources cheaper USD-denominated, short-term loans from local processors as pre-finance, especially for light crop beans.

Selling only 60 to $70 \%$ of the predicted harvest forward mitigates potential losses from terminal price risk and leaves some cocoa to be sold at the spot market, which allows CMC some leeway for speculation. However, the use of forward contracts as collateral for offshore borrowing limits CMC's negotiation position vis-à-vis buyers. The conventional loan syndicate calendar restricts CMC's selling window, and hence, prevents it from optimally timing its spot sales. Market participants are aware of CMC's constraints and factor this into their sourcing plans.

Further, the reliance of the Bank of Ghana on cocoa as a source of foreign exchange bears risk of politicisation of production and trade. In the 2014/15 season, CMC oversold by nearly 150,000 tonnes. The overselling happened in the wake of mounting economic difficulties, accompanied by a large depreciation of the Cedi and depleted foreign reserves. The depreciation of the Cedi resulted in a high volume of cocoa beans being smuggled to Côte d'Ivoire in the 2013/14 season. 
At the same time, the Ghanaian government was eager to increase its collateral for offshore borrowing to bring in much needed foreign reserves to prevent the Cedi from depreciating further, pressuring CMC to oversell. Today, the Foreign Exchange Act of 2016 (Act 723) is providing the Bank of Ghana greater control over foreign exchange circulating in the economy and with the right to introduce capital controls if necessary, to mitigate future impasses.

Forward contracts issued by CMC are standardised and referenced to cocoa futures prices traded at the Intercontinental Exchange (ICE) Europe in London (previously LIFFE), making these prices highly susceptible to financial speculation. The set-up ensures effective hedging for international buyers. It also makes cocoa income for the Ghanaian economy immediately dependent on price movements at the futures exchange. Heightened volatility and a delinking of prices from market fundamentals, hence, aggravate the challenges posed to commodity export earnings in producing countries. Additionally, futures traded at the ICE London are denominated in GBP, while standardised contracts for cocoa trading are denominated in USD, exposing CMC to a USD-GBP exchange rate risk. These macroeconomic challenges make a strong case for diversifying into cocoa bean processing to move into products such as industrial and consumer chocolate that are not immediately based on futures prices and are historically much less volatile.

However, cocoa bean exports remain the most important source of foreign reserves for the Bank of Ghana to stabilise domestic currency, since gold and oil export revenues are dominantly controlled by stronger private multinational firms. Selling less of the unprocessed cocoa beans forward implies less collateral for borrowing in USD at affordable rates. Upgrading strategies that include a system in which cocoa beans are sold to domestic buyers with smaller balance sheets and lower credit ratings than large multinationals or in which cocoa beans are sold in domestic currency would significantly reduce the value of the collateral usable for the syndicate loans.

\section{Processing at Origin and Upgrading Potential}

Ghana has a long history of cocoa processing. The West African Mills Company (WAMCO) was established in 1947, by UK Gill and Dufus. In 1966, the wholly government-owned Cocoa Processing Company (CPC) was established with a factory in Tema. WAMCO became state owned in 1982, and for a short period of time, operated under CPC. In 1992, WAMCO became a joint venture with a $60 \%$ ownership acquired by the German company Schroeder and Hosta, with the remaining shares held by the government. CPC was incorporated as a limited liability company in 1981 and publicly listed on the Ghana Stock Exchange in 2003. Cocobod remains the majority shareholder through debt-to-equity conversion.

Today, CPC comprises three factories - two cocoa factories and one confectionery factory. The cocoa factories process raw cocoa beans into semi-finished products (liquor, butter and powder), while the confectionery factory manufactures chocolate bars, couverture, chocolate-coated peanuts, drinking chocolate, and chocolate bars under the Golden Tree brand. As Golden Tree chocolate bars do not melt in 


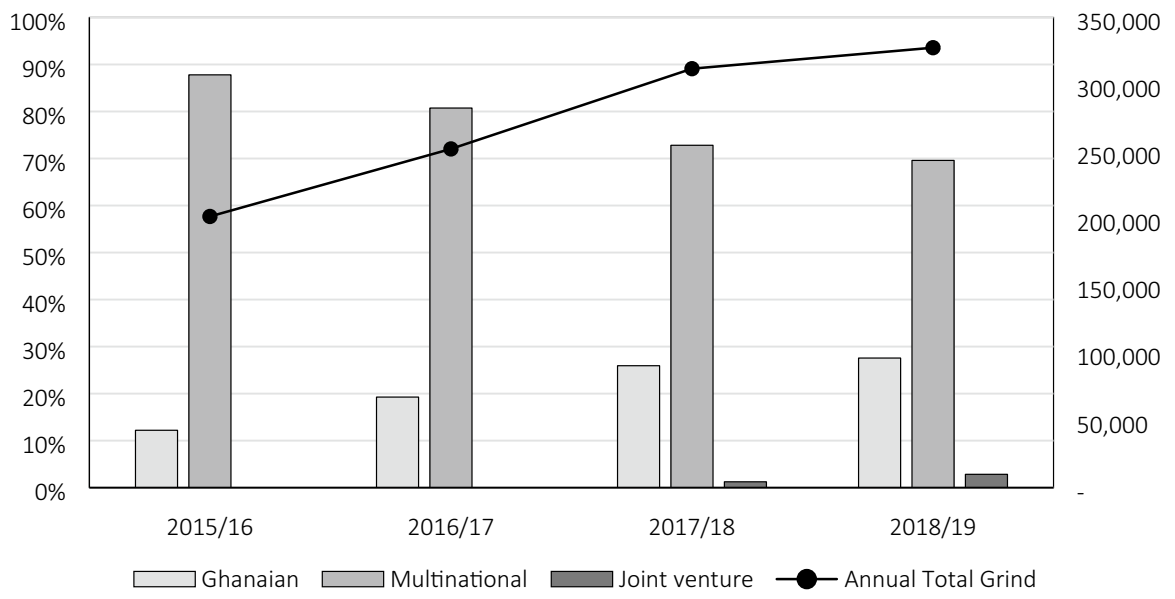

Fig. 7 Percentage share in domestic grinding by company ownership type. Listed from largest to smallest share in grinding, Ghanaian companies are Niche Cocoa Processing, Cocoa Processing Company (CPC), and Plot Enterprise. Foreign companies are Cargill, Barry Callebaut, Olam, Touton and BD Associates. WAMCO is the only joint venture. Source Data provided by CMC. Authors' calculations

high temperatures, domestic sales of the product through street vendors as well as in supermarkets is facilitated. WAMCO continues to produce semi-finished products but no consumer chocolate.

Despite obstacles to domestic processing, cocoa processed at origin has increased steadily over the last decade; see Fig. 7. The Ghanaian government incentivises domestic processing by offering a bean discount to domestic processors and establishing economic free zones for export-oriented companies (Goodman 2017). ${ }^{8}$ Free zones are located in Tema, Takoradi, and Kumasi, the three cocoa ports (Kumasi is an inland port). Companies that export a minimum of $70 \%$ of their products are eligible to register for the free zone, which provides various tax exemptions. Further, CMC sells light crop beans to domestic processors at a $20 \%$ discount. Other smaller sized beans can receive a discount up to $40 \%$ and beyond. In this way, Ghana maintains its high-quality premium on the international market, as lower quality beans are not exported, and processors get cheaper Ghanaian beans for input.

Through these incentives, Ghana was able to attract considerable foreign direct investment (FDI) inflow for cocoa processing. In 2000, Barry Callebaut opened a large processing plant in Tema. Cargill and ADM followed in 2008, with additional plants in Tema and Kumasi. Processing operations by ADM have since been acquired by Olam. The Kazakhstani BD Associates contributed additional processing capacity in 2008. More recently, Touton, a French soft commodity trading house has established sourcing capacity through Eliho LBC, entering the cocoa processing

\footnotetext{
${ }^{8}$ Light crop beans (up to 120 beans per $100 \mathrm{~g}$ ) would sell for a $10 \%$ discount on the international market. Ghana only exports main crop beans to maintain its quality premium. Annual exports to China in fulfilment of an agreement to fund the Bui Power Dam are the exception.
} 


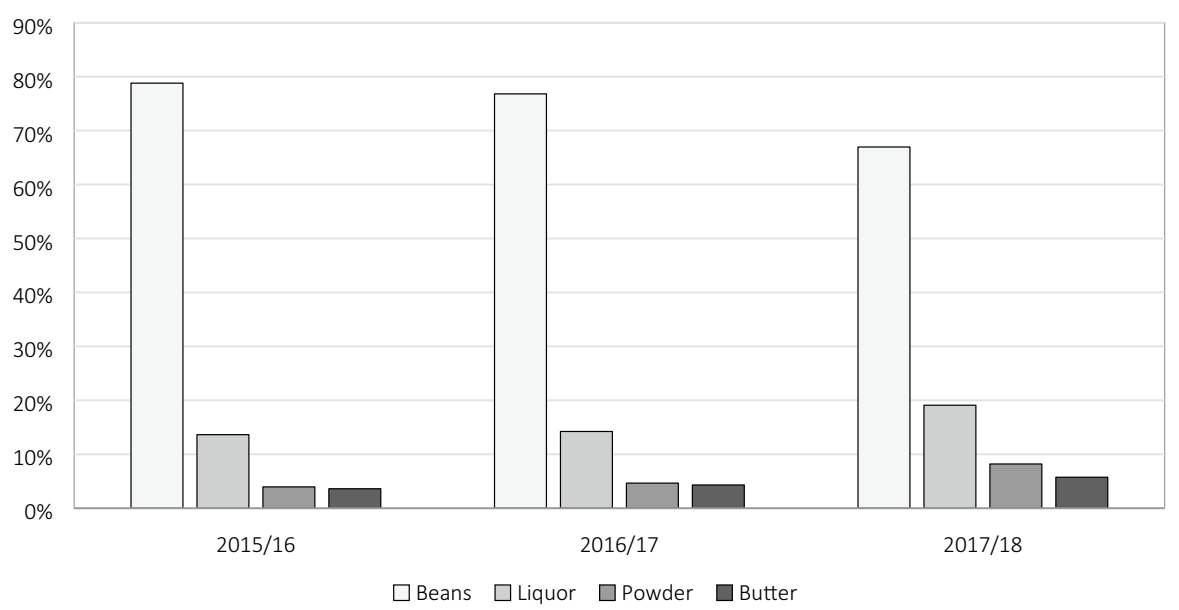

Fig. 8 Cocoa beans and products export share (share of total in beans equivalent). Source Data provided by CMC. Authors' calculations

business by acquiring existing capacity in Tema. Most foreign-owned companies produce only liquor. The exceptions are Cargill and BD Associates that produce liquor, butter and powder. Overall, liquor remains the main cocoa product exported; see Fig. 8.

However, prices for liquor and other cocoa products are often not negotiated, since they are traded within the company. In the 2018/19 crop year, 70\% of processed cocoa was produced by foreign-owned companies. The beans used for origin processing are commonly bought by the parent company in negotiations with CMC, and the processed intermediate products are shipped for further in-house processing or directed to a customer. While the arrangement ensures cocoa beans are bought in USD via CMC, the value addition, if happening intra-firm, does not benefit Ghana much, nor does it stabilise its cocoa income.

Interestingly, the share of powder and butter exports, the higher value cocoa products, has increased in recent years. This increase is driven predominantly by an expansion of processing capacity by domestically owned companies. Recently, two privately owned, domestic companies have added to local processing capacity and even chocolate production. Niche Cocoa Processing was established in Tema in 2007. Starting initially with liquor, since 2017, Niche has been producing large volumes of butter and powder, as well as consumer chocolate, which can be found in local supermarkets. Plot Enterprise, established in 2009 in Takoradi, produces liquor, butter and cake. In addition to local processing capacity, several small-scale artisan chocolate makers emerged in Ghana, e.g. 57 Chocolate, Midunu Chocolates and Chocoluv, supplying the domestic consumer market.

Domestic processing and chocolate production capabilities clearly exist, not least because of the partial liberalisation of the sector, which ensured that CPC and WAMCO remained operational. Further, domestically owned processors, especially, add value by exporting cocoa products, some to international buyers that do not own 
domestic processing capacity and use domestic companies for processing before shipment. However, despite apparent success in domestic processing expansion in recent years, growth remains slow, as domestic companies remain structurally disadvantaged with respect to their foreign-owned counterparts.

Since CMC does not sell cocoa beans in domestic currency, processing companies require large sums of USD for bean sourcing. Foreign-owned companies finance their bean purchases via their highly leveraged and financialised parent companies, tapping into offshore markets. Even if these companies borrow domestically, they get cheaper rates, as well as larger amounts via domestic banks than do their Ghanaian counterparts. ${ }^{9}$ The minimum capital requirement for commercial banks in Ghana is 400 million Cedi (USD70 million equivalent), an amount that could buy about 30,000 tonnes of raw beans. However, the 'single obligor limit' for commercial banks in Ghana is set at $25 \%$ for a single secured borrower and $10 \%$ for a single unsecured borrower (Pwc 2019). Ghanaian-owned companies fall into the latter category. The maximum USD amount they can borrow from a single commercial bank finances about 3000-7500 tonnes of beans, well below their minimum sourcing requirement of 30,000 tonnes of beans. As a result, local processors are forced to borrow piecemeal, adding to their funding costs.

Access to USD is a substantial limiting factor for domestic processors, and all four domestic processors are indebted to Cocobod, as they have failed to pay for their bean purchases in the past. As a result, domestic companies are now required to pay CMC in advance, while international buyers pay upon receipt of beans-a necessary measure to maintain CMC's cashflow position. Further, domestic processors often lack knowledge and experience in the use of derivative markets to minimise risk exposure, resulting, for instance, in cocoa beans being processed without having secured a buyer for the products. Foreign-owned processors are fully integrated into their parent company's supply system, providing them with a vast network for their products. Independent processors, on the other hand, must find buyers. Some rely on external marketing companies that are responsible for multiple companies. Markets for butter and powder are very different, with butter being in high demand in Europe while powder having a good market in the United States and Asia. Depending on the focus and location of the external marketing company, cocoa processors might receive an order for one of the products, leaving them with the other one unsold, resulting in storage costs and a financing gap.

For the partially state-owned companies CPC and WAMCO, Cocobod arrived at a unique solution that provides these companies with access to risk management expertise as well as markets. Traders at CMC go through years of rigorous training in financial derivative trading, including shadowing of commodity traders. This provides them with a unique set of skills and a wide network. After WAMCO experienced severe financial difficulties with debt to Cocobod in 2016, CMC agreed to a new sales system in which CMC handles the marketing of WAMCO's cocoa

\footnotetext{
${ }^{9}$ Domestic banks charge about $13 \%$ interest on USD loans. Domestic processors also borrow from international trade finance banks, such as the Africa Exim Bank, which offer more competitive rates at around $6-7 \%$.
} 
products to ensure recouping of bean costs. A similar strategy has been agreed for the sales of CPC products. By selling forward the cocoa products to international buyers, CMC ensures recovery of the bean costs before delivering raw beans to WAMCO for processing. The system ensures access to beans without the USD requirements and leverages expertise and network of CMC to market the products.

Despite these measures, competing internationally remains difficult for most domestically owned processors. However, a reorientation towards the domestic or regional market is discouraged by the current incentive structure, which is geared towards protection of foreign exchange earnings from cocoa beans. In order to remain a beneficiary of the free zone tax exemptions, Niche has decoupled its confectionery business from its grinding operations. Further, a significant disincentive for domestic cocoa consumption is an extreme tax rate of $60 \%$ on domestic sales. Only for cocoa powder, which is the lower value factor, are programmes geared towards the domestic market considered, e.g. Ghana's school feeding programmes that include drinking chocolate.

The unique structure of the Ghanaian cocoa sector has, on the one hand, preserved domestic capabilities and promoted value addition, and, on the other hand, restrained the sectors' efforts to move into higher value addition due to its pivotal role in foreign exchange provision, a dilemma that is difficult but not impossible to overcome, judging by the success of Niche in chocolate production for the domestic market and by the ingenious marketing of domestic cocoa products through CMC.

\section{Conclusion}

We have shown that the lead segments of the cocoa-chocolate chain are highly financialised. For the brander segment, we identify financialisation of objectives and investment. Growth in the segment has taken place predominantly through horizontal integration, outsourcing low-ROCE activities to boost shareholder value and acquiring of a portfolio of brand names managed via holding companies. Financialisation of the first-tier supplier segment additionally encompasses financialisation of operations with first-tier suppliers diversifying into different upstream segments of the supply chain, including financial service provision. Not coincidentally, all major first-tier suppliers have headquarters in global financial centres. Competing in these lead firm segments without the same access to international financial markets or capabilities in financial trading is not a feasible functional upgrading strategy for developing and emerging market companies.

At the same time, incentives for value addition in the Ghanaian cocoa-chocolate sector are firmly geared towards foreign exchange earnings, a necessity arising based on the country's subordinate position in the global financial architecture. Any upgrading strategy that impedes foreign exchange earnings threatens the Bank of Ghana's ability to stabilise the domestic currency and effectively manage the country's macroeconomy. The two policies providing incentives for origin processing, tax exemptions and bean subsidies, are clear symptoms of this constraint. Processing is only encouraged if it contributes to foreign exchange 
earnings, either by exporting intermediate cocoa products or increasing the quality premium of the exported main crop beans.

Despite these obstacles, Ghanaian-owned processing companies have significantly contributed to the country's increase in cocoa processing, and chocolate production for the domestic market is growing. Ingenious measures introduced by Cocobod have supported this development. The new arrangement between CMC and WAMCO eliminates the company's USD requirements and minimises financing costs and quantity risk, thereby overcoming some of the key constraints faced by domestically owned processors. This service could be extended to privately owned processors and either be assumed by a business association or remain within $\mathrm{CMC}$, with a trading team selling cocoa products alongside beans.

The syndicate loan system provides Ghana with unique access to cheap USDdenominated credit. However, it also undermines CMC's ability to time its sales optimally. The current COVID-19 pandemic-induced economic crisis has demonstrated this shortcoming. The crisis fuelled global financial slowdown and a liquidity crunch for commodity finance banks and trade houses. Further, sluggish demand for chocolate exposed CMC painfully as it was forced to sell an adequate volume of forward contracts in a falling market to meet its annual syndicated timeline of September. Still, CMC's creditworthiness was questioned, despite having never defaulted and having been able to repay its 2019/20 loan two months before its due date.

A possible solution could be the arrangement of several smaller syndicate loans spread evenly over the year or an ambitious approach where the Bank of Ghana provides a local currency equivalence of what $\mathrm{CMC}$ requires for its internal marketing operation. The latter would offer CMC the possibility to gradually wean itself from the sole reliance on offshore financing. The former would enable CMC to time its sales more favourably and smooth the annual inflow of foreign exchange. A greater independence for Cocobod as well as an ease in reliance on cocoa syndicated loans by the Bank of Ghana would also be desirable to avoid pressure on CMC to oversell or sell in times of low terminal prices.

While the institutional structure of the Ghanaian cocoa sector is unique, the trade-offs faced by the Ghanaian government in designing suitable policies for functional upgrading are arguably shared by many primary commodity exporting economies. Further research in this area is needed to identify differences and similarities between commodities and commodity exporting economies.

\section{Compliance with Ethical Standards}

Conflict of interest Author 2 is an employee with the Cocoa Marketing Company GH Ltd, Accra. 


\section{References}

Acquaah, B. 1999. Cocoa development in West Africa: The early period with particular reference to Ghana. Accra: Ghana University Press.

Auvray, T. and J. Rabinovich, 2017. The financialisation-offshoring nexus and the capital accumulation of U.S. nonfinancial firms. CEPN Working Papers 2017-02, Centre d'Economie de l'Université de Paris Nord.

Baines, J. 2017. Accumulating through food crisis? farmers, commodity traders and the distributional politics of financialization. Review of International Political Economy 24 (3): 497-537.

Bair, J. 2005. Global capitalism and commodity chains: Looking back, going forward. Competition \& Change 9 (2): 153-180.

Bair, J., and M. Werner. 2011. Commodity chains and the uneven geographies of global capitalism: A disarticulations perspective. Environment and Planning A: Economy and Space 43 (5): 988-997.

Bair, J., C. Berndt, M. Boeckler, and M. Werner. 2013. Guest editorial. Environment and Planning A: Economy and Space 45 (11): 2544-2552.

Baud, C., and C. Durand. 2011. Financialization, globalization and the making of profits by leading retailers. Socio-Economic Review 10 (2): 241-266.

Behuria, P. 2019. The domestic political economy of upgrading in global value chains: How politics shapes pathways for upgrading in Rwanda's coffee sector. Review of International Political Economy 27 (2): 348-376.

Bonizzi, B. 2013. Financialization in developing and emerging countries. International Journal of Political Economy 42 (4): 83-107.

Bonizzi, B., A. Kaltenbrunner, and J. Powell. 2019. Subordinate financialization in emerging capitalist economies. In The Routledge International Handbook of Financialization, Chapter 15, ed. P. Mader, D. Mertens, and N. van der Zwan. Abingdon: Routledge.

Burch, D., and G. Lawrence. 2009. Towards a third food regime: Behind the transformation. Agriculture and Human Values 26 (4): 267-279.

Clapp, J. 2014. Financialization, distance and global food politics. The Journal of Peasant Studies 41 (5): $797-814$.

Clapp, J. 2015. ABCD and beyond: From grain merchants to agricultural value chain managers. Canadian Food Studies/La Revue canadienne des études sur l'alimentation 2 (2): 126.

Clapp, J., and E. Helleiner. 2012. Troubled futures? The global food crisis and the politics of agricultural derivatives regulation. Review of International Political Economy 19 (2): 181-207.

Clapp, J., and S.R. Isakson. 2018. Risky returns: The implications of financialization in the food system. Development and Change 49 (2): 437-460.

De Marchi, V., E. Giuliani, and R. Rabellotti. 2017. Do global value chains offer developing countries learning and innovation opportunities? European Journal of Development Research 30 (3): 389-407.

De Medeiros, C.A.N.T. 2017. Inequality and income distribution in global value chains. Journal of Economic Issues 51 (2): 401-408.

Dolan, C., and J. Humphrey. 2000. Governance and trade in fresh vegetables: The impact of UK supermarkets on the African horticulture industry. Journal of Development Studies 37 (2): 147-176.

Epstein, G. 2019. Financialization, rentier interests and central bank policy. In The Political Economy of Central Banking, Chapter 14, pp. 380-406. Northampton, MA: Edward Elgar Publishing.

Erb, C.B., and C.R. Harvey. 2006. The strategic and tactical value of commodity futures. Financial Analysts Journal 62 (2): 69-97.

Fagerberg, J., B.-А․ Lundvall, and M. Srholec. 2018. Global value chains, national innovation systems and economic development. European Journal of Development Research 30 (3): 533-556.

Fold, N. 2001. Restructuring of the European chocolate industry and its impact on cocoa production in west Africa. Journal of Economic Geography 1 (4): 405-420.

Fold, N. 2002. Lead firms and competition in "bi-polar" commodity chains: Grinders and branders in the global cocoa-chocolate industry. Journal of Agrarian Change 2 (2): 228-247.

Fold, N. 2007. Transnational sourcing practices in Ghana's perennial crop sectors. Journal of Agrarian Change 8 (1): 94-122.

Fold, N., and M.N. Larsen. 2011. Upgrading of smallholder agro-food production in Africa: The role of lead firm strategies and new markets. International Journal of Technological Learning, Innovation and Development 4 (1/2/3): 39. 
Froud, J., C. Haslam, S. Johal, and K. Williams. 2000. Shareholder value and financialization: Consultancy promises, management moves. Economy and Society 29 (1): 80-110.

Gereffi, G. 1999. International trade and industrial upgrading in the apparel commodity chain. Journal of International Economics 48 (1): 37-70.

Ghosh, J. 2010. The unnatural coupling: food and global finance. Journal of Agrarian Change 10 (1): 72-86.

Gibbon, P. 2001. Upgrading primary production: A global commodity chain approach. World Development 29 (2): 345-363.

Gilbert, C.L. 2016. The dynamics of the world cocoa price. In The economics of chocolate, ed. M.P. Squicciarini and J. Swinnen, 307-338. Oxford: Oxford University Press.

Goodman (2017). Investing in Ghana's cocoa processing industry: Opportunities, risks and the competitive advantage. Technical report, Goodman AMC LLC.

Gorton, G., and K.G. Rouwenhorst. 2006. Facts and fantasies about commodity futures. Financial Analysts Journal 62 (2): 47-68.

Haslam, C., T. Andersson, N. Tsitsianis, and Y.P. Yin. 2013. Redefining business models: Strategies for a financialized world. London: Routledge.

Hauge, J. 2020. Industrial policy in the era of global value chains: Towards a developmentalist framework drawing on the industrialisation experiences of South Korea and Taiwan. World Economy 43 (8): 2070-2092.

Horner, R., and M. Alford. 2019. The roles of the state in global value chains. In Handbook on global value chains, ed. S. Ponte, G. Gereffi, and G. Raj-Reichert, 555-569. Cheltenham: Edward Elgar Publishing.

Humphrey, J. and H. Schmitz (2000). Governance and upgrading: Linking industrial cluster and global value chain research. Technical report, IDS Working Paper 120.

Humphrey, J., and H. Schmitz. 2002. How does insertion in global value chains affect upgrading in industrial clusters? Regional Studies 36 (9): 1017-1027.

Humphrey, J., and H. Schmitz. 2004. Chain governance and upgrading: Taking stock. In Local enterprises in the global economy: Issues of governance and upgrading, ed. H. Schmitz, 349-382. Cheltenham, UK: Edward Elgar Publishing.

Isakson, S.R. 2014. Food and finance: The financial transformation of agro-food supply chains. The Journal of Peasant Studies 41 (5): 749-775.

Kaltenbrunner, A., and J.P. Painceira. 2014. Developing countries' changing nature of financial integration and new forms of external vulnerability: The Brazilian experience. Cambridge Journal of Economics 39 (5): 1281-1306.

Kaltenbrunner, A., and J.P. Painceira. 2017. Subordinated financial integration and financialisation in emerging capitalist economies: The Brazilian experience. New Political Economy 23 (3): 290-313.

Kaplinsky, R. 1998. Globalisation, industrialisation and sustainable growth: The pursuit of the nth rent. IDS Discussion Paper 365.

Lazonick, W., and M. O'Sullivan. 2000. Maximizing shareholder value: A new ideology for corporate governance. Economy and Society 29 (1): 13-35.

Lee, K., M. Szapiro, and Z. Mao. 2017. From global value chains (GVC) to innovation systems for local value chains and knowledge creation. European Journal of Development Research 30 (3): 424-441.

Lombardozzi, L. 2020. Unpacking state-led upgrading: Empirical evidence from Uzbek horticulture value chain governance. Review of International Political Economy. https://doi.org/10.1080/09692 290.2020.1737563.

Maizels, A. 1994. The continuing commodity crisis of developing countries. World Development 22 (11): 1685-1695.

Mayer, J. 2012. The growing financialisation of commodity markets: Divergences between index investors and money managers. Journal of Development Studies 48 (6): 751-767.

Mayer, F., and N. Phillips. 2017. Outsourcing governance: States and the politics of a 'global value chain world.' New Political Economy 22 (2): 134-152.

Mikell, G. 1989. Cocoa and chaos in Ghana. New York: Paragon House.

Milberg, W., and D. Winkler. 2009. Financialisation and the dynamics of offshoring in the USA. Cambridge Journal of Economics 34 (2): 275-293.

Murphy, S., D. Burch, and J. Clapp. 2012. Cereal secrets: The world's largest grain traders and global agriculture. Oxfam.

Nissanke, M. 2012. Commodity market linkages in the global financial crisis: Excess volatility and development impacts. Journal of Development Studies 48 (6): 732-750. 
Palpacuer, F. 2008. Bringing the social context back in: Governance and wealth distribution in global commodity chains. Economy and Society 37 (3): 393-419.

Palpacuer, F., and S. Tozanli. 2008. Changing governance patterns in European food chains: The rise of a new divide between global players and regional producers. Transnational Corporations 17 (1): 69-98.

Pipkin, S., and A. Fuentes. 2017. Spurred to upgrade: A review of triggers and consequences of industrial upgrading in the global value chain literature. World Development 98: 536-554.

Ponte, S., and P. Gibbon. 2005. Quality standards, conventions and the governance of global value chains. Economy and Society 34 (1): 1-31.

Powell, J. (2013). Subordinate financialisation: A study of Mexico and its non-financial corporations. Ph. D. Thesis, SOAS University of London.

Pwc (2019). Ghana banking survey: Banking reforms so far: Topmost issues on the minds of bank ceos. Technical report, pwc.

Rossi, A. 2013. Does economic upgrading lead to social upgrading in global production networks? Evidence from morocco. World Development 46: 223-233.

Salerno, T. 2014. Capitalising on the financialisation of agriculture: Cargill's land investment techniques in the Philippines. Third World Quarterly 35 (9): 1709-1727.

Salerno, T. 2016. Cargill's corporate growth in times of crises: How agro-commodity traders are increasing profits in the midst of volatility. Agriculture and Human Values 34 (1): 211-222.

Talbot, J.M. 2002. Tropical commodity chains, forward integration strategies and international inequality: Coffee, cocoa and tea. Review of International Political Economy 9 (4): 701-734.

Vicol, M., J. Neilson, D.F.S. Hartatri, and P. Cooper. 2018. Upgrading for whom? relationship coffee, value chain interventions and rural development in Indonesia. World Development 110: 26-37.

Working, H. 1960. Speculation on hedging markets. Food Research Institute Studies 1: 185-220.

Publisher's Note Springer Nature remains neutral with regard to jurisdictional claims in published maps and institutional affiliations. 